\title{
Assessment of Heavy Metal Pollution in Sediment and Polychaete Worms from the Mzinga Creek and Ras Dege Mangrove Ecosystems, Dar es Salaam, Tanzania
}

\author{
A. Mtanga and J. Machiwa \\ University of Dar es Salaam, Department of Aquatic Environment and Conservation, P.O. Box 35064, Dar es \\ Salaam, Tanzania
}

\begin{abstract}
Keywords: Anthropogenic impacts, Mangrove sediment, Polychaete worms, Capitella sp., Heavy metals, Mzinga creek, Ras Dege
\end{abstract}

\begin{abstract}
Metal pollution in the Mzinga creek mangrove stand was assessed and compared with a relatively pristine mangrove forest at Ras Dege in Dar es Salaam. The concentrations of cadmium, chromium, copper, lead and zinc in sediment and polychaete worms (Capitella sp.) were analyzed by ICP-AES and mercury was analyzed by a semi-automatic analyzer. Concentrations of most of the metals analyzed were higher in samples from Mzinga creek than from Ras Dege. Sediment samples from the Mzinga creek were enriched with $\mathrm{Cu}(\mathrm{EF}=7.4), \mathrm{Hg}(\mathrm{EF}=5.3)$ and $\mathrm{Cr}(\mathrm{EF}$ $=3.3$ ) relative to sediment samples from Ras Dege, which were mostly at natural background levels. Polychaete worm samples from the Mzinga creek also accumulated high amounts of metals when compared to samples from Ras Dege. The data show perturbation of the Mzinga creek from human activities in the catchment.
\end{abstract}

\section{INTRODUCTION}

East African mangroves and the associated biota are decreasing in areal coverage because of overexploitation for wood and tannin, clearance for agriculture, tourist resorts, saltpans and settlements (Wagner et al., 1999; Semesi, 1991). Removal of mangrove forests has direct and indirect influences on aquatic organisms, as it deprives them of habitats as well as feeding and breeding grounds. Some mangrove areas in East Africa have been used as dumping sites for solid wastes and for sewage disposal. Such practices have resulted in the increase in levels of metals in the aquatic environment. Some studies have already indicated potential threat to mangrove ecosystems in Tanzania as a result of pollution from heavy metals (de Wolf et al., 2001; Mremi \& Machiwa,
2003). However, the extent of enrichment of heavy metals in mangrove ecosystems in relation to natural background levels in the region has not been adequately addressed.

Polychaete worms are one of the dominant infauna of soft bottom substrates and exhibit high stability and adaptability to different habitats (Sarkar et al., 2005). Polychaete worms (Capitela capitata) are common in mangrove sediment and they serve as important descriptors of environmental conditions (Fisher et al., 2000) and good indicators of sediment quality. In the present study sediment and polychaete worms have been used as proxies to assess the extent of metal pollution. The concentration of metals in the geochemically available sediment fraction (easily reducible and oxidisable phases) is analysed to assess the extent of vulnerability of infauna. 


\section{MATERIAL AND METHODS}

\section{Study area}

The Mzinga creek mangrove stand is about $2.5 \mathrm{~km}$ south of Dar es Salaam harbour. The mangrove stand on Mzinga creek lies between latitude 06 - $52.330^{\prime}$ to $06^{\circ} 53.059^{\prime} \mathrm{S}$ and longitude $039^{\circ}$ $17.556^{\circ}$ to $039^{\circ} 18.599^{\prime}$ E (Fig. 1). Activities in
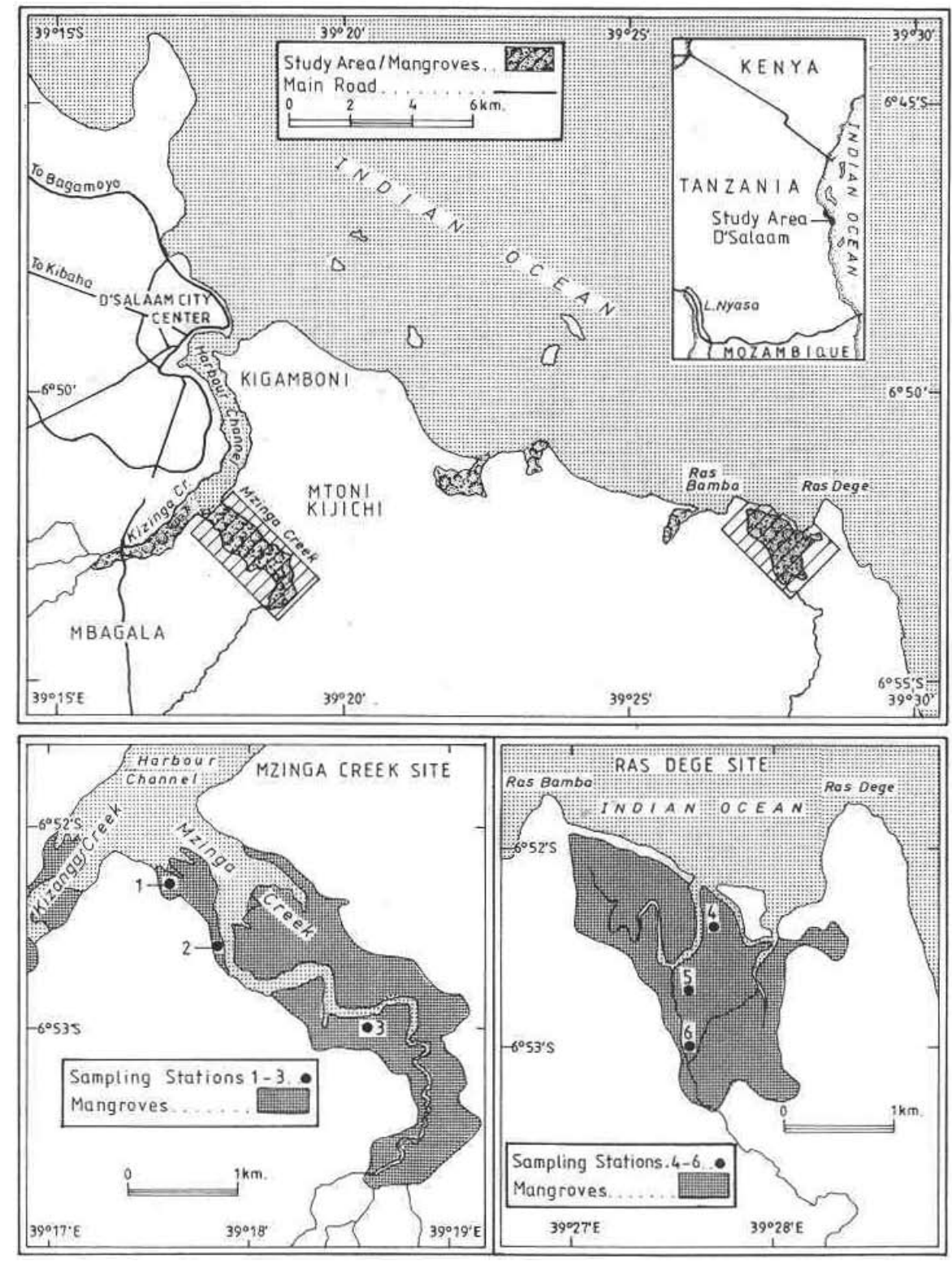

Fig. 1. Map of Dar es Salaam Coast showing the study sites, the potentially impacted Mzinga creek and relatively less impacted Ras Dege mangrove stands the area include agriculture, fishing and mangrove harvesting, the site also receives runoff from residential and agricultural areas. The Ras Dege mangrove stand is located approximately $60 \mathrm{~km}$ south of Dar es Salaam, between latitude $06^{\circ}$ $52.389^{\prime}$ to $06^{\circ} 53.071^{\prime} \mathrm{S}$ and longitude $039^{\circ} 27.689^{\prime}$ to $039^{\circ} 27.620^{\prime} \mathrm{E}$. It is remote from the city and less affected by human activity and was used as a reference site for assessing the extent of metal pollution in Mzinga creek.

\section{Sampling and analysis of sediment and} polychaete worm samples

Sampling of sediment was conducted during September 2005 in Mzinga creek and Ras Dege mangrove forests during low tide, using a hand corer $(30 \mathrm{~cm}$ height, $6 \mathrm{~cm}$ internal diameter) Sediment core samples were collected in triplicate from stations $1-6$ (Fig. 1). Surface sediment $(0$ $-2 \mathrm{~cm}$ ) samples of the core were sliced and freeze dried, and then sieved through $1 \mathrm{~mm}$ nylon scree and thoroughly homogenized. A sub-sample of the bulk sediment was overnight extracted with hydrofluoric acid $(40 \%, 60 \mathrm{ml})$, then $15 \mathrm{M}$ nitric acid $(15 \mathrm{ml})$ was added and the solution wa evaporated to dryness on a hot plate. The residue was dissolved in $3 \mathrm{M}$ nitric acid $(10 \mathrm{ml})$, filtered through $0.45-\mu \mathrm{m}$ membrane filter and the final volume was adjusted with distilled deionized water (Thomson and Wash, 2003). Total $\mathrm{Cu}, \mathrm{Cd}, \mathrm{Pb} \mathrm{Cr}, \mathrm{Zn}$ $\mathrm{Al}$, and $\mathrm{Fe}$ were analyzed with Inductively Coupled Plasma-Atomic Emission Spectrometer (ICP$\mathrm{AES}$ ). Fe values are not reported here, and $\mathrm{Al}$ values were used to calculate metal enrichment factors for use in the discussion. Another sub-sample of the bulk sediment was sequentially extracted in orde to obtain metals from the reducible and oxidisable phases (the geochemically available fraction of metals). Samples of $2.0 \mathrm{~g}$ finely powdered bulk sediment were placed in $100 \mathrm{ml}$ polypropylen centrifuge tubes. The first leach, the reducible fraction, contains metals from hydrous oxides of iron and manganese as well as the aged poorly crystallized oxides of iron and carbonates in the sediment as well as exchangeable ions (Murray $e t$ al., 2000). $20 \mathrm{ml}$ of $0.04 \mathrm{M}$ hydroxylammonium chloride (HA) in 25\% acetic acid (HOAc) was added in the tubes. The samples were heated at $96^{\circ} \mathrm{C}$ in a water bath for 8 hours with intermitten agitation, and then centrifuged at $3000 \mathrm{rpm}$ for 30 min. The supernatant solution was acidified with concentrated nitric acid and evaporated to dryness. The residues were dissolved in $1.0 \mathrm{M}$ nitric acid (5 $\mathrm{ml}$ ) in a volumetric flask and analyzed for metal (Ahlf et al., 2002). For the second leach, nitric acid $(0.02 \mathrm{M}, 10 \mathrm{ml})$ was added to the sample that previously had been leached with HA/ HOAc (stil in the centrifuge tubes). After heating for 2 hours at $85^{\circ} \mathrm{C}$ in a water bath, with occasional agitation of the sample, $30 \%$ hydrogen peroxide $(10 \mathrm{ml}$ at $\mathrm{pH} 2$ ) was added. The sample was reheated for 3 hours with intermittent shaking; $3.2 \mathrm{M}$ ammonium acetate in $20 \%(\mathrm{v} / \mathrm{v})$ nitric acid $(10 \mathrm{ml})$ was added to the cooled sample. Finally, the sample was centrifuged for 30 minutes at $3000 \mathrm{rpm}$ and the supernatant liquid was decanted into a beaker. The solution was evaporated to dryness and the residues were re-dissolved in $10 \mathrm{ml}$ nitric acid $(0.02 \mathrm{M})$ and filtered through a $0.45 \mu \mathrm{m}$ membrane filter. The final volume was made with $1.0 \mathrm{M}$ nitric acid, metals bound in labile organic complexes and insoluble sulfides were analyzed. Total mercury in the sediment samples was extracted according to Akagi \& Nishimula (1991). A dry sediment sample $(0.5 \mathrm{~g})$ was accurately weighed into a beaker, distilled water $(1 \mathrm{ml})$ was added and mixed with $2 \mathrm{ml}$ of concentrated nitric acid/perchloric acid (1:1) and $5 \mathrm{ml}$ of concentrated sulfuric acid. The solution was heated on a hot plate at $200 \pm 5^{\circ}$ for 30 $\mathrm{min}$. Distilled water was added to make $50 \mathrm{ml}$, total mercury determined using a semiautomatic mercury analyzer (Sanso Seisakusho HG 201)

Polychaete worms were dug out of sediment at stations $1-6$ (Fig. 1) using a shovel, with about 60 worms collected from each station. The sediment was sieved on a $2 \mathrm{~mm}$ mesh sieve in order to retain worms and larger particles. Polychaete worms (Capitela sp.) were collected, depurated and washed. Identification of worms was conducted using standard taxonomic literature (e.g. Richmond, . The worms were oven dried at $50^{\circ} \mathrm{C}$ and crushed into fine powder. $1 \mathrm{~g}$ of a well homogenized powder was accurately weighed into $100 \mathrm{ml}$ flask. Samples were digested with a mixture of $16 \mathrm{ml}$ of concentrated $\mathrm{HNO}_{3}$ and $4 \mathrm{ml}$ of concentrated $\mathrm{HClO}_{4}$ acid. The mixture was heated on a hot plate for 1 hour then cooled. The digest was transferred into a $50 \mathrm{ml}$ volumetric flask and diluted to the mark with $2 \mathrm{M}$ nitric acid. The solution was analyzed for $\mathrm{Cd}$, $\mathrm{Cr}, \mathrm{Cu}, \mathrm{Pb}$ and $\mathrm{Zn}$ using ICP-AES. Total mercury was analysed by accurately weighing approximately $0.5 \mathrm{~g}$ (wet weight) of worm sample into a digestion flask. Distilled water $(1 \mathrm{ml})$ was added in the flask and mixed with $2 \mathrm{ml}$ of concentrated nitric acid/ perchloric acid (1:1) and $5 \mathrm{ml}$ of sulfuric acid. The solution was heated on a hot plate at $200 \pm 5^{\circ} \mathrm{C}$ for 30 min. Distilled water was added to make $50 \mathrm{ml}$, total $\mathrm{Hg}$ was analyzed by Semiautomatic $\mathrm{Hg}$ analyzer. 
Quality assurance/control included procedural blanks and analysis of Certified Reference Materials (CRMs): DORM-2 (dogfish muscle), DOLT-2 (dogfish liver) and PACS-2 (marine sediment). Variation between sample replicates was less than 5 $\%$, the accuracy of the results was good with respect to the certified values (Table 1).

Statistical analyses were based on the significance level at $\mathrm{P}=0.05$ and critical values of $\mathrm{F}$ at $\alpha=0.05$. Single factor analysis of variance (ANOVA) was used for data analysis.

Differences in metal concentrations between Mzinga creek and Ras Dege mangrove stands were compared using student's $t$ test (Zar, 1996).

Table 1. Comparison of certified values for the certified reference materials (CRMs) with analytical results of the concentration of metals $\left(\mu \mathrm{g} \mathrm{g}^{-1}\right.$ except $\left.\mathrm{Hg}, \mathrm{ng} \mathrm{g}^{-1}\right)$ in CRMs obtained by University of Dar es Salaam laboratory

\begin{tabular}{llcccccc}
\hline CRMs & & Cd & Cr & Cu & Hg & Pb & Zn \\
\hline DOLT -2 & Certified value & 20.8 & 0.37 & 25.8 & 2.14 & 0.22 & 85.8 \\
& Observed concentration & 19.6 & 0.34 & 23.44 & 2.17 & 0.29 & 81.5 \\
& \% Recovery & $94 \%$ & $91 \%$ & $90 \%$ & $101 \%$ & $131 \%$ & $94 \%$ \\
DORM-2 & Certified value & 0.043 & 34.7 & 2.34 & 4.64 & 0.065 & 25.6 \\
& Observed concentration & 0.045 & 32 & 2.1 & 4.24 & 0.063 & 22.3 \\
& \% Recovery & $104 \%$ & $92 \%$ & $89 \%$ & $91 \%$ & $96 \%$ & $87 \%$ \\
PACS-2 & Certified value & 2.11 & 90.7 & 310 & 3.04 & 183 & 364 \\
& Observed concentration & 1.95 & 86.4 & 300.2 & 2.80 & 177 & 340 \\
& \% Recovery & $92 \%$ & $95 \%$ & $96 \%$ & $82 \%$ & $96 \%$ & $93 \%$ \\
\hline
\end{tabular}

\section{RESULTS}

Cadmium concentration in sediment and polychaete worms

Bulk sediment samples from Mzinga creek had total Cd concentration of $1.05 \pm 0.04 \mu \mathrm{g} \mathrm{g}^{-1} \mathrm{dw}$ and those from Ras Dege had $1.00 \pm 0.23 \mu \mathrm{g} \mathrm{g}^{-1} \mathrm{dw}$. A Student $t$ test indicated no significant difference $(t$ (10) $0.461, P>0.05$ ) between Cd concentration in bulk sediment samples from the two locations. The concentration of $\mathrm{Cd}$ in the reducible sediment phase of samples from Mzinga creek was $0.07 \pm 0.01 \mu \mathrm{g}$ $\mathrm{g}^{-1} \mathrm{dw}$, in the oxidisable phase was $0.06 \pm 0.02 \mu \mathrm{g}$ $\mathrm{g}^{-1} \mathrm{dw}$. The geochemically available $\mathrm{Cd}$ was $12 \%$ of the total concentration and $46 \%$ of the available $\mathrm{Cd}$ in the surface sediment was associated with labile organic matter and possibly to a lesser extent with sulfide minerals. For Ras Dege sediment samples, the concentration of $\mathrm{Cd}$ in the reducible phase was
$0.02 \pm 0.001 \mu \mathrm{g} \mathrm{g}^{-1} \mathrm{dw}, 0.04 \pm 0.01 \mu \mathrm{g} \mathrm{g}^{-1} \mathrm{dw}$ in the oxidisable phase. The geochemically available Cd was only $6 \%$ of the total concentration. About $67 \%$ of the available Cd in the Ras Dege surface sediment was associated with organic matter and probably some sulfide minerals. The concentration of $\mathrm{Cd}$ in polychaete worms from Mzinga creek was $3.3 \pm 0.7 \mu \mathrm{g} \mathrm{g}^{-1} \mathrm{dw}$ and in samples from Ras Dege was $0.1 \pm 0.08 \mu \mathrm{g} \mathrm{g}^{-1} \mathrm{dw}$. A Student $t$ test showed a significant difference in $\mathrm{Cd}$ concentration between worm samples from Mzinga creek and Ras Dege mangrove stands ( $\mathrm{t}(10)$ 10.979, $\mathrm{P}<0.001)$

\section{Chromium concentration in sediment and} polychaete worms

The concentration of total $\mathrm{Cr}$ in bulk sediment samples was $22.7 \pm 0.5 \mu \mathrm{g} \mathrm{g}^{-1} \mathrm{dw}$ in samples from Mzinga creek and $19.9 \pm 4.8 \mu \mathrm{g} \mathrm{g}^{-1} \mathrm{dw}$ in Ras Dege samples (Fig. 3). A Student $t$ test showed no significant difference ( $($ (10) $0.461, P>0.05$ ) between the concentration of $\mathrm{Cr}$ in bulk sediment samples from the two sites. The reducible phase of Mzinga creek mangrove sediment contained $6.1 \pm 1.8 \mu \mathrm{g} \mathrm{Cr} \mathrm{g}^{-1} \mathrm{dw}, \mathrm{Cr}$, the oxidisable phase had $1.5 \pm 0.6 \mu \mathrm{g} \mathrm{Cr} \mathrm{g}^{-1} \mathrm{dw}$, forming $34 \%$ as the geochemically available $\mathrm{Cr}$. Out of the available $\mathrm{Cr}$ in Mzinga creek surface sediment, only about $20 \%$ was associated with organic matter and sulfide minerals. The concentration of $\mathrm{Cr}$ in the reducible phase of sediment samples from Ras Dege was $1.1 \pm 0.9 \mu \mathrm{g} \mathrm{g}^{-1} \mathrm{dw}$ and in the oxidisable phase was $1.5 \pm 0.5 \mu \mathrm{g} \mathrm{g}^{-1} \mathrm{dw}$. The available $\mathrm{Cr}$ in the sediment was $13 \%$ of the total concentration,

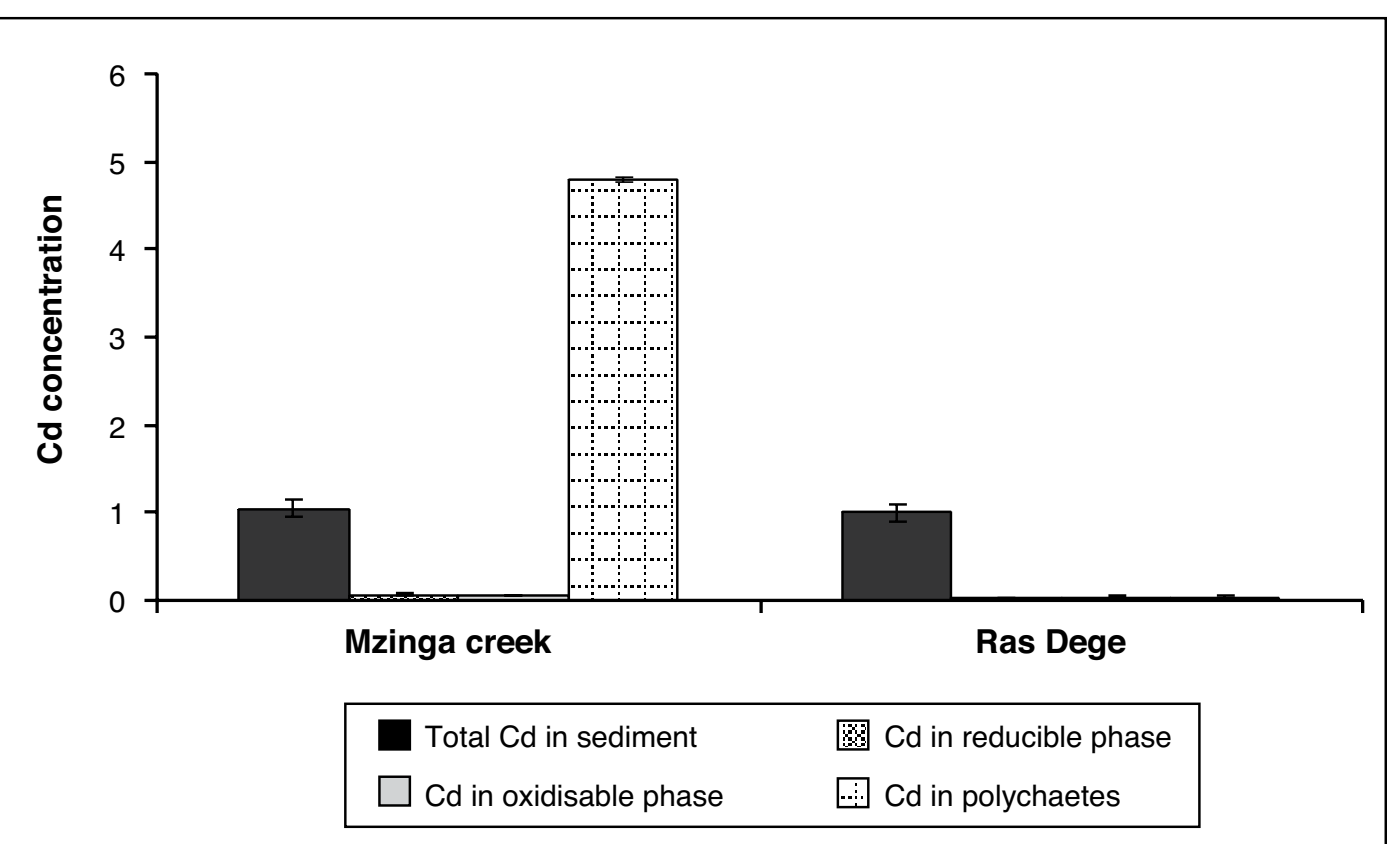

Fig. 2. Mean \pm SEM concentration of $\mathrm{Cd}\left(\mu \mathrm{g} \mathrm{g}^{-1} \mathrm{dw}\right)$ in sediment and polychaete worms from Mzinga creek and Ras Dege mangrove stands

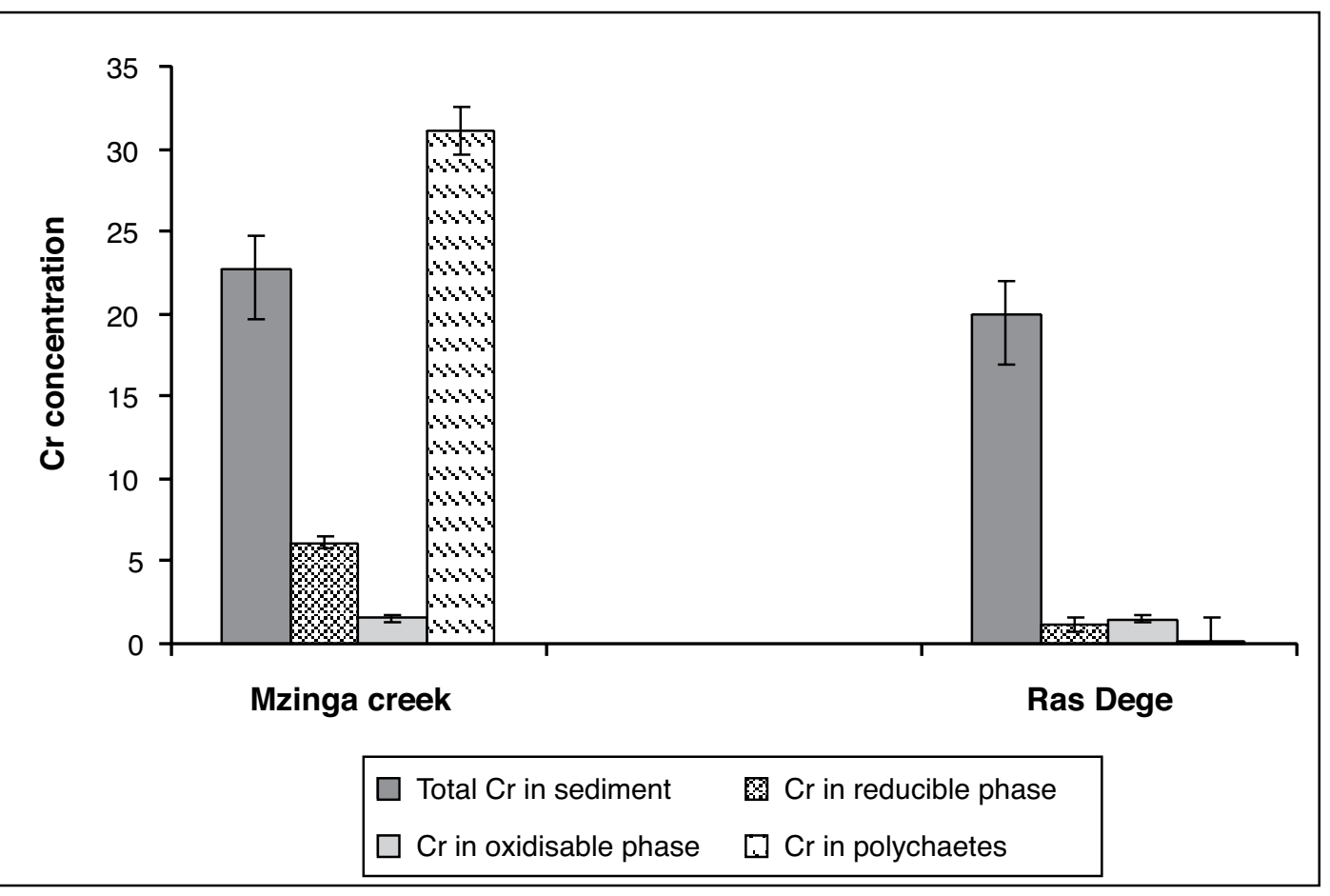

Fig. 3. Mean $\pm \mathrm{SEM}$ concentration of $\mathrm{Cr}\left(\mu \mathrm{g} \mathrm{g}^{-1} \mathrm{dw}\right)$ in sediment and polychaete worms from Mzinga creek and Ras Dege mangrove stands 
of which about $58 \%$ was associated with organic matter and to a lesser extent with sulfide minerals. The concentration of $\mathrm{Cr}$ in worm samples from Mzinga creek was $31.1 \pm 15.1 \mu \mathrm{g} \mathrm{g}^{-1} \mathrm{dw}$ and in Ras Dege samples was $0.2 \pm 0.1 \mu \mathrm{g} \mathrm{g}^{-1} \mathrm{dw}$, the difference was significant ( $\mathrm{t}(10) 4.295, \mathrm{P}=0.002)$.

\section{Copper concentration in sediment and} polychaete worms

The concentration of total $\mathrm{Cu}$ in the bulk sediment samples from Mzinga creek was $9.5 \pm 2.1 \mu \mathrm{g} \mathrm{g}^{-1} \mathrm{dw}$ and from Ras Dege was $4.9 \pm 2.6 \mu \mathrm{g} \mathrm{g}^{-1} \mathrm{dw}$ (Fig. 4) the difference between the concentrations for the two sites was significant ( $t(10) 3.047, \mathrm{P}=0.012$ ). Copper in the reducible phase of sediment samples from Mzinga creek mangrove stand was $3.7 \pm 2.2 \mu \mathrm{g}$ $\mathrm{g}^{-1} \mathrm{dw}$ and in the oxidisable phase was $0.8 \pm 0.4 \mu \mathrm{g}$ $\mathrm{g}^{-1} \mathrm{dw}$. The available $\mathrm{Cu}$ in the sediment was $47 \%$ of the total concentration. Only a small proportion of the available $\mathrm{Cu}$ (about 18\%) in the surface sediment in Mzinga creek was associated with organic matter and probably sulfide minerals. The concentrations of $\mathrm{Cu}$ in the reducible and oxidisable phases of sediment samples from Ras Dege were $0.03 \pm 0.01 \mu \mathrm{g} \mathrm{g}^{-1} \mathrm{dw}$ and $0.65 \pm 0.14 \mu \mathrm{g} \mathrm{g}^{-1} \mathrm{dw}$ respectively. The concentration of available $\mathrm{Cu}$

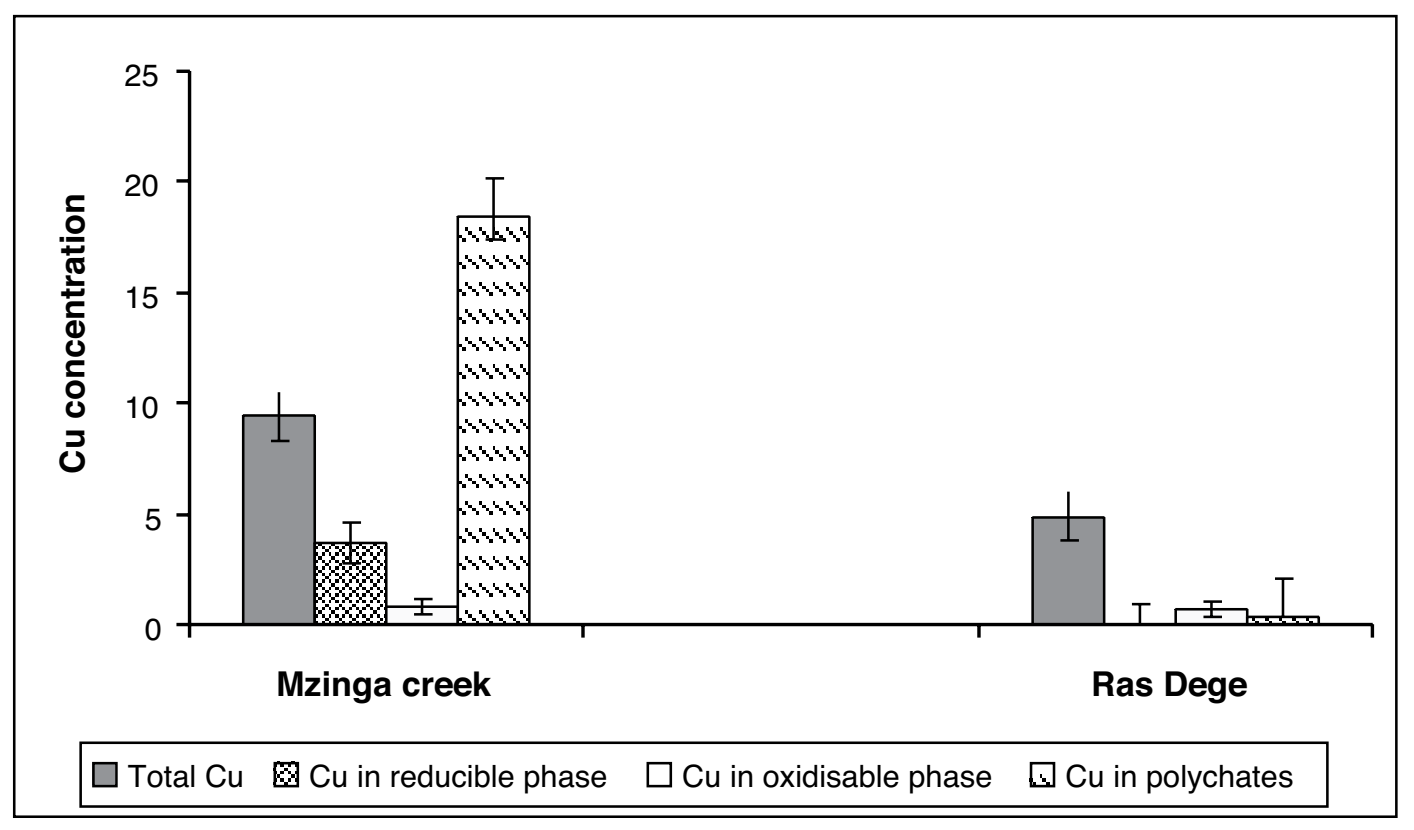

Fig. 4. Mean \pm SEM concentration of $\mathrm{Cu}\left(\mu \mathrm{g} \mathrm{g}^{-1} \mathrm{dw}\right)$ in sediment and polychaetes from Mzinga creek and Ras Dege mangrove stands

was $14 \%$ of the total. In Ras Dege sediments, most of the available $\mathrm{Cu}($ about $96 \%$ ) was associated with organic matter and possibly sulfide minerals forming the oxidisable phases. The concentration of $\mathrm{Cu}$ in polychaete worm samples from Mzinga creek was $18.4 \pm 4.2 \mu \mathrm{g} \mathrm{g}^{-1} \mathrm{dw}$ and from Ras Dege was $0.3 \pm 0.2 \mu \mathrm{g} \mathrm{g}^{-1} \mathrm{dw}$, the difference was significant (t (10) $10.589, \mathrm{P}<0.001)$

Lead concentration in sediment and polychaete worms

The concentration of total $\mathrm{Pb}$ in the bulk sediment samples (Fig. 5) was higher (14.6 $\pm 2.3 \mu \mathrm{g} \mathrm{g}^{-1} \mathrm{dw}$ ) in samples from Mzinga creek than Ras Dege $(8.2 \pm 0.8$ $\mu \mathrm{g} \mathrm{g}^{-1} \mathrm{dw}$ ), and the difference was significant ( $\mathrm{t}(10) 6.595, \mathrm{P}<0.001)$. Lead concentration in the reducible fraction of sediment samples from Mzinga creek was $4.5 \pm 1.3 \mu \mathrm{g} \mathrm{g}^{-1} \mathrm{dw}$ and the oxidisable phase contained $1.5 \pm 0.6 \mu \mathrm{g} \mathrm{g}^{-1} \mathrm{dw}$. The concentration of available $\mathrm{Pb}$ in the sediment was $41 \%$ of the total, only $25 \%$ of the available $\mathrm{Pb}$ was associated with organic matter and sulfide minerals. For samples from Ras Dege, the concentration of $\mathrm{Pb}$ in the reducible phase was $1.3 \pm 0.4 \mu \mathrm{g} \mathrm{g}^{-1} \mathrm{dw}$ and in the oxidisable phase was $1.0 \pm 0.4 \mu \mathrm{g} \mathrm{g}^{-1} \mathrm{dw}$. The available $\mathrm{Pb}$ was $28 \%$ of the total concentration and

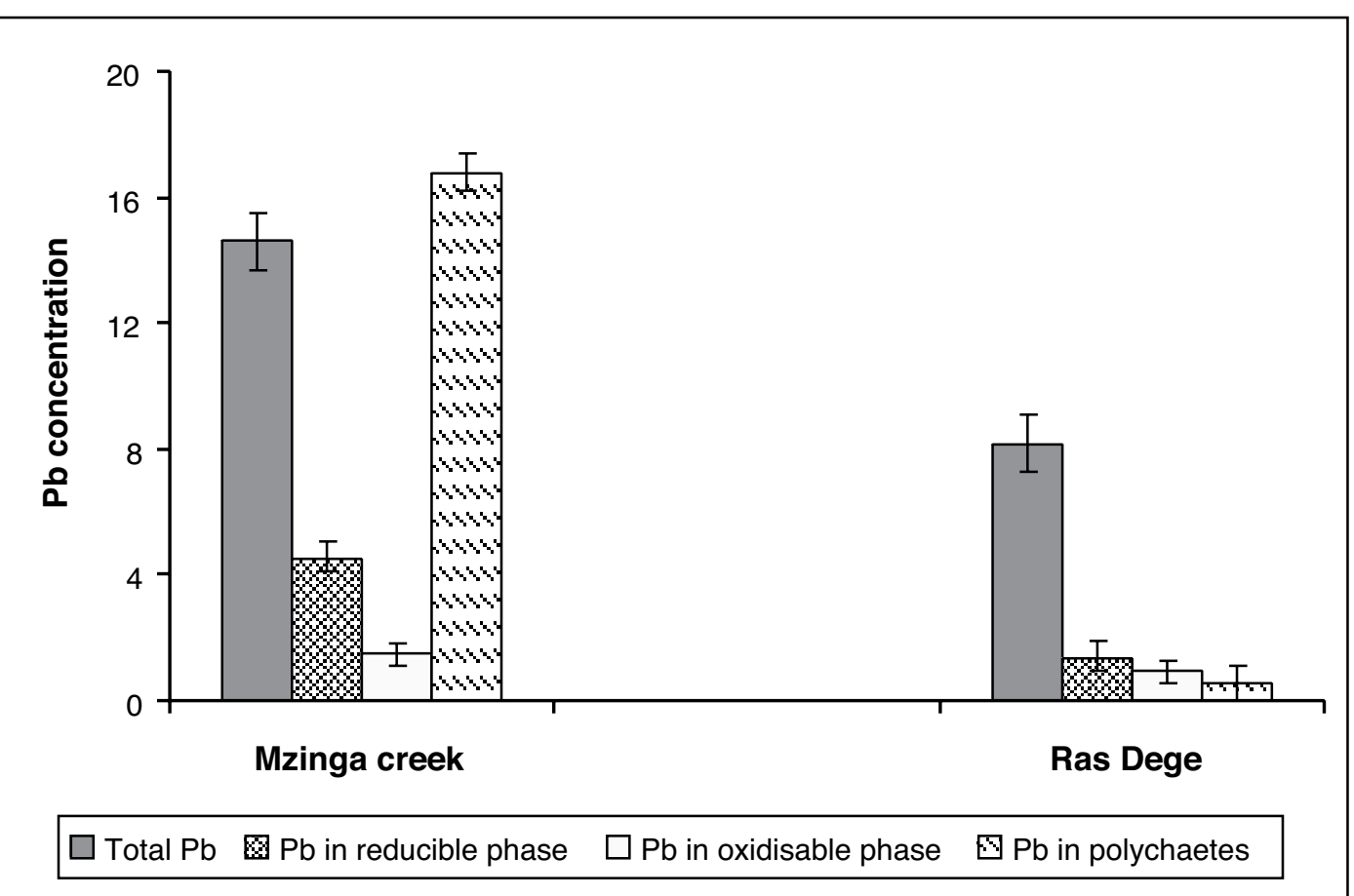

Fig. 5. Mean \pm SEM concentration of $\mathrm{Pb}\left(\mu \mathrm{gg}^{-1} \mathrm{dw}\right)$ in sediment and polychaete worms from Mzinga creek and Ras Dege mangrove stands

$43 \%$ of the available $\mathrm{Pb}$ was associated with organic matter and sulfide minerals. The concentration of $\mathrm{Pb}$ in polychaete worms was higher $(16.8 \pm 1.4 \mu \mathrm{g}$ $\mathrm{g}^{-1} \mathrm{dw}$ ) in samples from Mzinga creek than samples from Ras Dege $\left(0.6 \pm 0.2 \mu \mathrm{g} \mathrm{g}^{-1} \mathrm{dw}\right)$, the difference was significant $(\mathrm{t}(10) 28.068, \mathrm{P}<0.001)$.

\section{Zinc concentration in sediment and} polychaete worms

The concentration of total $\mathrm{Zn}$ in bulk sedimen samples was $35.1 \pm 7.1 \mu \mathrm{g} \mathrm{g}^{-1} \mathrm{dw}$ and $19.6 \pm 7.3 \mu \mathrm{g}$ $\mathrm{g}^{-1} \mathrm{dw}$ for samples from Mzinga creek and for Ras Dege respectively (Fig. 6), and the difference was statistically significant $(\mathrm{t}(10) 3.72, \mathrm{P}=0.004)$. The concentrations of $\mathrm{Zn}$ in the reducible and oxidisable phases of sediment samples from Mzinga creek were $10.2 \pm 4.4 \mu \mathrm{g} \mathrm{g}^{-1} \mathrm{dw}$ and $6.6 \pm 1.3 \mu \mathrm{g} \mathrm{g}^{-1} \mathrm{dw}$ respectively (Fig. 6). About $48 \%$ of total $\mathrm{Zn}$ was in the geochemically reactive phases. About $39 \%$ of the available $\mathrm{Zn}$ in the surface sediment of Mzinga creek was associated with organic matter and sulfide minerals. For sediment samples from Ras Dege, the concentrations of $\mathrm{Zn}$ in sediment phases were 2.1 $\pm 0.8 \mu \mathrm{g} \mathrm{g}^{-1} \mathrm{dw}$ in the reducible and $1.4 \pm 0.1 \mu \mathrm{g}$ $\mathrm{g}^{-1} \mathrm{dw}$ in the oxidisable phases. The geochemically available $\mathrm{Zn}$ was $18 \%$ of the total concentration, $40 \%$ of the available zinc in the surface sediment was associated with organic matter and sulfides. Zinc concentration in polychaete worms was $58.7 \pm$ $2.0 \mu \mathrm{g} \mathrm{g}^{-1} \mathrm{dw}$ and $15.6 \pm 2.8 \mu \mathrm{g} \mathrm{g}^{-1} \mathrm{dw}$ in samples from Mzinga creek and Ras Dege respectively, and the difference was statistically significant $(\mathrm{t}(10)$ $4.570, \mathrm{P}=0.001$ )

\section{Mercury concentration in sediment and} polychaete worms

The concentration of total $\mathrm{Hg}$ in mangrove sediment (Fig. 7) was significantly higher (t (10) 5.472, (P< 0.001) in samples from Mzinga creek (93.38 \pm 33.40 $\left.\mathrm{ng} \mathrm{g}^{-1} \mathrm{dw}\right)$ than Ras Dege $\left(17.45 \pm 5.79 \mathrm{ng} \mathrm{g}^{-1} \mathrm{dw}\right)$. Total $\mathrm{Hg}$ concentration was also significantly higher ( $t(10) 2.910, P=0.016)$ in polychaete worms from Mzinga creek $\left(511.19 \pm 4.30 \mathrm{ng} \mathrm{g}^{-1} \mathrm{ww}\right)$ than in samples from Ras Dege $\left(23.10 \pm 6.20 \mathrm{ng} \mathrm{g}^{-1} \mathrm{ww}\right)$. 


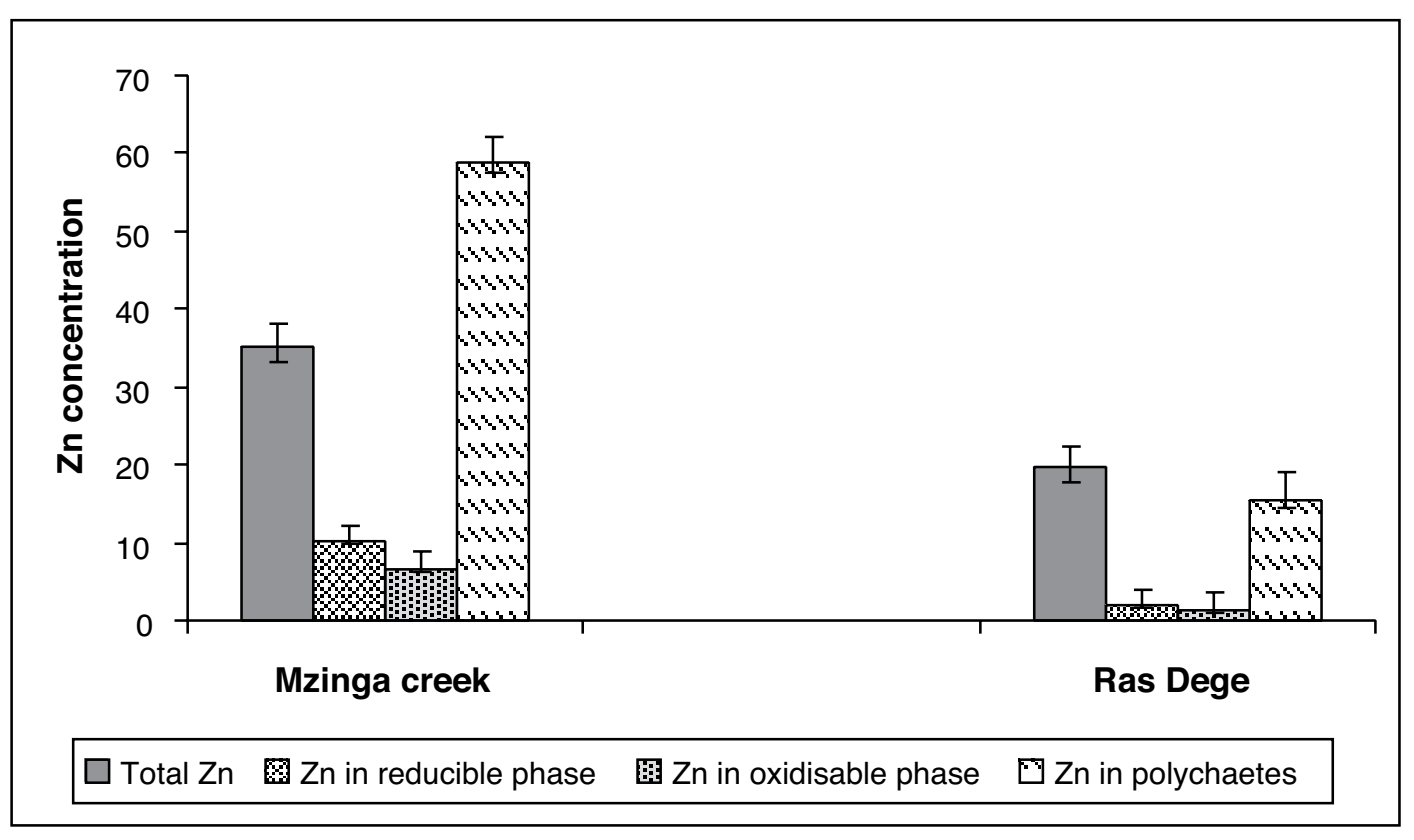

Fig. 6. Mean \pm SEM concentration of $\mathrm{Zn}\left(\mu \mathrm{g} \mathrm{g}^{-1} \mathrm{dw}\right)$ in sediment and polychaete worms from Mzinga creek and Ras Dege mangrove stands

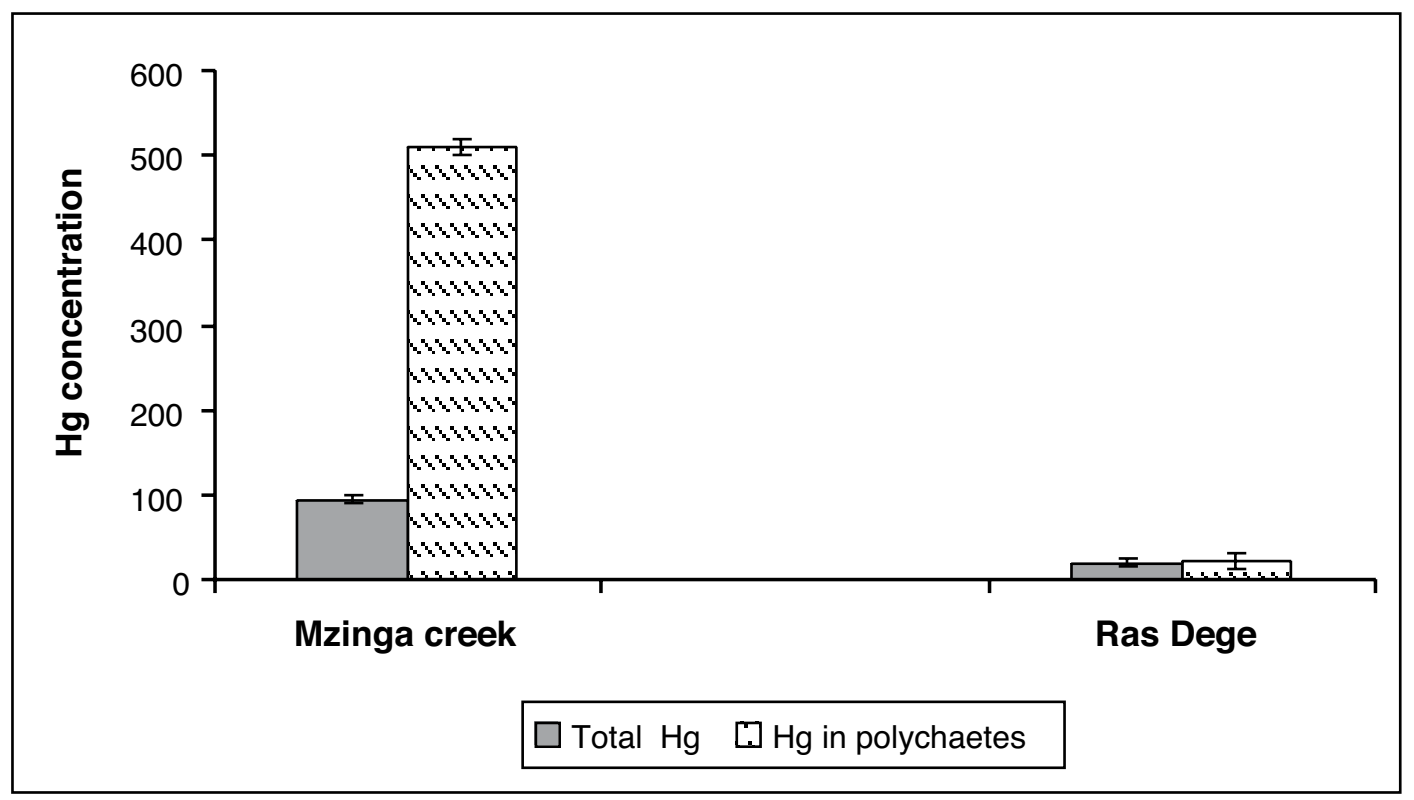

Fig. 7. Mean \pm SEM concentration of $\mathrm{Hg}\left(\mathrm{ng} \mathrm{g}^{-1}\right)$ sediment (dry weight) and polychaete worms (wet weight) from Mzinga creek and Ras Dege mangrove stands

\section{DISCUSSION}

Enrichment of metals in the mangrove sediments

The enrichment factors $(\mathrm{EF})$ for metals in the sediments of the Mzinga creek and Ras Dege mangrove stands were calculated with respect to crustal values of respective elements (Camusso $e$ al. 2002; Martin \& Whitfield, 1983) normalized to $\mathrm{Al}$ concentration.

$$
E F=\frac{(\mathrm{Me} / \mathrm{Al})_{S}}{(\mathrm{Me} / \mathrm{Al})_{C}}
$$

Where: $(\mathrm{Me} / \mathrm{Al})_{S}$ is the ratio of the concentration of the element of interest to aluminium in the sediment and $(\mathrm{Me} / \mathrm{Al})_{C}$ is the ratio of the element to $\mathrm{Al}$ in the crust.

$\mathrm{EF}^{1}$ relative to earth's crust for metals in sedimen samples from Mzinga creek were $>1$ (Table 2), with Cd having the highest $\mathrm{EF}$ of 15.8 followed by $\mathrm{Hg}$ (3.5). Sediment samples from Ras Dege had EF $\leq 1$ relative to average crust values. Hence, the concentrations of metals in Ras Dege sediments were assumed as a good representative of natura background values. The EF values for metals in

Table 2. Heavy metal concentration $\left(\mu \mathrm{g} \mathrm{g}^{-1}\right)$ in sediment from Mzinga Creek and Ras Dege compared with sediment quality guidelines (ANZECC and ARMCANZ, 2000). Also shown are Enrichment Factors of metals in Mzinga Creek and Ras Dege sediments relative to crust values $\left(\mathbf{E F}^{1}\right)$ as well Enrichment Factors of metals in Mzinga Creek relative to Ras Dege levels $\left(\mathbf{E F}^{2}\right)$

\begin{tabular}{|c|c|c|c|c|c|c|c|}
\hline & \multicolumn{2}{|c|}{ CONCENTRATION } & \multicolumn{2}{|c|}{ ANZECC } & \multirow{2}{*}{$\begin{array}{c}\mathbf{E F}^{1} \\
\text { Mzinga C. }\end{array}$} & \multirow{2}{*}{$\begin{array}{c}\mathbf{E F}^{1} \\
\text { Ras Dege }\end{array}$} & \multirow{2}{*}{$\begin{array}{c}\mathbf{E F}^{2} \\
\text { Mzinga C }\end{array}$} \\
\hline & Mzinga C. & Ras Dege & *Low & *High & & & \\
\hline $\mathrm{Cd}$ & $1.05 \pm 0.04$ & $1.20 \pm 0.20$ & 1.5 & 10 & 15.8 & 1.0 & 2.0 \\
\hline $\mathrm{Cr}$ & $22.7 \pm 0.5$ & $19.9 \pm 4.8$ & 80 & 370 & 3.2 & 1.0 & 3.3 \\
\hline $\mathrm{Cu}$ & $9.5 \pm 2.7$ & $4.9 \pm 2.6$ & 65 & 270 & 1.0 & 0.3 & 7.4 \\
\hline $\mathrm{Hg}$ & $0.09 \pm 0.01$ & $0.02 \pm 0.01$ & 0.15 & 1 & 3.5 & 1.1 & 5.3 \\
\hline $\mathrm{Pb}$ & $14.6 \pm 2.3$ & $8.2 \pm 0.8$ & 50 & 220 & 1.2 & 0.6 & 2.1 \\
\hline $\mathrm{Zn}$ & $35.1 \pm 7.1$ & $19.6 \pm 7.3$ & 200 & 410 & 1.9 & 1.5 & 2.9 \\
\hline
\end{tabular}

ANZECC and ARMCANZ, 2000 - Australian and New Zealand Guidelines for Fresh and Marine Water Quality Conch, and Agriculture and Resource Management Council of Australia and New Zealand) cited in Cox and Preda, 2005.

*Low sediment quality guideline - Trigger value above which further ecosystem specific investigation is recommended

*High sediment quality guideline - Highly contaminated sediments which are likely to have a biological impact, further

investigation is required. Dege sediments. Mzinga creek sediment are presented in Table 2. In relatively higher natural background concentration in the mangrove sediments relative to the average crust value. Higher $\mathrm{EF}^{2}>5$ were observed for $\mathrm{Cu}$ any case, comparison of metal levels with natural background concentrations where they exist, rather Despite the observed enrichment, the concentrations of metals in Mzinga creek mangrove sediment criteria (Table 2).

\section{Heavy metal pollution}

The concentration of total $\mathrm{Cd}$ analyzed in sedimen sediment samples from Ras Dege. The calculated $\mathrm{EF}$ of $\mathrm{Cd}$ in Mzinga creek sediment relative to Ras Dege sediment was 2. The EF for Cd in Mzinga creek was lower compared to the EF > 26 reported the reducible and oxidisable sediment phases in 
Mzinga creek mangrove sediments was higher ( $12.4 \%$ of the total Cd in the sediment) than in Ras Dege sediments ( $6 \%$ of the total $\mathrm{Cd}$ in sediment) indicating high bio-availability and potential bioaccumulation. Indeed, polychaete worms from Mzinga creek had 33 times higher $\mathrm{Cd}$ concentration than in samples from Ras Dege. The available $\mathrm{Cd}$ was equally distributed in the oxide/carbonate minerals and organic matter in the sediment.

The concentration of $\mathrm{Cr}$ in sediment samples from Mzinga creek was higher than in samples from Ras Dege suggesting input of the metal from the catchment. Mremi and Machiwa (2003) reported similar values of $\mathrm{Cr}$ in Msimbazi, Mtoni and Mbweni mangrove forests along the Dar es Salaam coast. The concentration of geochemically available Cr was higher in Mzinga creek mangrove sediments ( $34 \%$ of total Cr in sediment) than in Ras Dege (13 $\%$ of the total $\mathrm{Cr}$ in sediment). The high proportion of bio-available Cr in Mzinga creek sediments was reflected by the higher concentration of $\mathrm{Cr}$ in the polychaete worm samples. The concentration of $\mathrm{Cr}$ in polychaete worms from Mzinga creek was approximately 155 times higher than in samples from Ras Dege. Higher levels of $\mathrm{Cr}(22 \pm 4-164$ $\left.\pm 14 \mu \mathrm{g} \mathrm{g}^{-1}\right)$ in worms have been reported by Sarka et al. (2005) in Sundarban mangrove forest in India where the source of $\mathrm{Cr}$ was discharge from a nearby tannery.

The concentration of $\mathrm{Cu}$ in sediment from Mzinga creek was about twice higher than in samples from Ras Dege. The concentration of geochemically available $\mathrm{Cu}$ was higher in Mzinga creek sediment ( $48 \%$ of total $\mathrm{Cu}$ ) compared with Ras Dege (14\% of total $\mathrm{Cu}$ ), suggesting a large amount of bio-available $\mathrm{Cu}$ as reflected in the worms. Polychaete worms from Mzinga creek had about fifty seven-fold higher concentration of $\mathrm{Cu}$ than in samples from Ras Dege, indicating accumulation of the metal by infauna. Most of the bio-available $\mathrm{Cu}$ was associated with oxide/ carbonate minerals in Mzinga creek sediments, whereas in Ras Dege, $96 \%$ was associated with organic matter/sulfide minerals suggesting in situ natural sources.

Total $\mathrm{Pb}$ in Mzinga creek sediment was about double the concentration in sediment samples from Ras Dege. The concentration of geochemically available $\mathrm{Pb}$ was higher $(41 \%$ of total $\mathrm{Pb})$ in sediment samples from Mzinga creek compared with Ras Dege sediments (27\% of total $\mathrm{Pb}$ ). The high concentration of geochemically available $\mathrm{Pb}$ in Mzinga creek sediment indicates mobility in the environment (Muniz et al., 2004; Amusan and Adeniyi, 2005) as confirmed in the worms sampled. The concentration of $\mathrm{Pb}$ in polychaete samples from Mzinga creek was 32 times higher than in samples from Ras Dege.

The total concentration of $\mathrm{Zn}$ in sediment was 1.6 times higher in Mzinga creek than Ras Dege and the EF was 2.9 relative to Ras Dege sediments. The concentration of $\mathrm{Zn}$ in Mzinga creek sediments was lower compared to $68.2 \mu \mathrm{g} \mathrm{g}^{-1} \mathrm{dw}$ reported by Ong et al. (2006) in Kerteh mangrove sediment in Malaysia. The concentration of $\mathrm{Zn}$ in the geochemically available phases of sediment samples from Mzinga creek was higher ( $48 \%$ of total $\mathrm{Zn}$ ) than in samples from Ras Dege (18\% of total $\mathrm{Zn}$ ), suggesting higher bio-availability in Mzinga creek sediments. Nevertheless, the concentration of $\mathrm{Zn}$ in polychaete worms from Mzinga creek was only about fourfold higher than in samples from Ras Dege, suggesting involvement of physiological/ metabolic effects by the organism. However, Sarkar et al. (2005) reported higher concentrations of $\mathrm{Zn}\left(78-126 \mu \mathrm{g} \mathrm{g}^{-1} \mathrm{dw}\right)$ in polychaete worms in mangrove sediments in India.

The concentration of total Hg was five times higher in mangrove sediment samples from Mzinga creek than in samples from Ras Dege, the EF relative to Ras Dege sediment was 3.5 indicating contamination. Mirlaen et al. (2003) reported higher concentrations of $\mathrm{Hg}\left(20-17,840 \mathrm{ng} \mathrm{g}^{-1} \mathrm{dw}\right)$ in estuarine sediments in south Brazil, the hotspot areas corresponded with anthropogenic discharges of wastes directly in the estuary. Polychaete worm samples from Mzinga creek had 22 times higher $\mathrm{Hg}$ than in samples from Ras Dege suggesting $\mathrm{Hg}$ contamination.

Generally, it is obvious that Mzinga creek mangrove stand is threatened with metal pollution. The level of metals in the sediments is alarming if compared with the Ras Dege mangrove stand which is far from Dar es Salaam city. Even though the levels of metals are within the recommended sediment quality criteria, necessary management steps have to be taken. There is an urgent need to minimize input of domestic and industrial wastes in
Mzinga creek catchment and in the Dar es Salaam harbour.

Acknowledgement-The anonymous reviewers are thanked for their critical comments. This study was funded by the research project PUMPSEA - 'Periurban mangroves forests as filters and potentia phytoremediators of domestic sewage in Eas Africa' (INCO-CT2004-510863), funded by the European Union. The authors also thank laboratory scientists in the Faculty of Aquatic Sciences and Technology and the Department of Geology for field and laboratory assistance.

\section{REFERENCES}

Akagi, H. \& Nishimura, B. 1991. Mercury speciatio in the environment. In: Suzuki, T., Imura, and Clarkson, T.W (eds). Advances in Mercury Toxicology Plenum Press, New Yolk pp 53-76.

Ahlf, W., Hollert, H., Neumann-Hensel, H. \& Ricking. M. 2002. A guidance for the Assessment and evaluation of sediment quality. J. Soils and Sediments 13: 351-356.

Amusan, A.A \& Adeniyi I.F. 2005. Genesis, classification and heavy metal retention Potentia of soils in mangrove forest, Niger Delta, Nigeria. J. Human Ecol. 17: 255 - 261.

Camusso, M., Galassi. S. \& Vignati, D. 2002. Assessment of river Po sediment quality by micropollutant analysis. Water Res. 36: 249 $-2504$.

Cox, M.E. \& Preda, M. 2005. Trace Metal Distribution within Marine and Estuarine Sediments of Western Moreton Bay, Queensland, Australia: Relation to land use and setting. Geographical Res. 42: 173 $-193$.

De Wolf, H., Ulomi, S.A., Backeljau, T., Pratap, H.B. \& Blust, R. 2001. Heavy metal levels in the sediments of four Dar es Salaam mangroves: Accumulation in, and effect on the morphology of the periwinkle, Littoraria scabra (Mollusca: Gastropoda). Environ. Int. 26: $243-249$.

Fisher, W.S., Oliver, L. M., Winstead J.T \& Long, E. R. 2000. A survey of oyster Crassostrea virginica R. 2000. A survey of oyster Crassostrea virginica from Tampa Bay, Florida: Associations of internal defense measurements with con

Aquat. Toxicol. 15: $115-138$.
Kamau, J.N. 2002. Heavy metal distribution and enrichment at Port - Reitz creek Mombas Western Indian Ocean J. Mar. Sci. 1: 65 - 70.

Martin, J.M. \& Whitfied, M. 1983. The significance of River inputs to the ocean. In C. S. Wong, E. Bayle, K. W, Bruland, J. D. Bruton \& E.D. Goldberg (eds). Trace metals in Seawater. Plenum Press, New York

Mirlaen, N., Andrus, V.E. \& Baisch, P. 2003. Mercury pollution sources in sediments of Patos Lagoon estuary, Southern Brazil. Mar. Pollut. Bull. 46: $331-334$.

Mremi, S.D. \& Machiwa, J.F. 2003. Heavy metal contamination of mangrove sediments and the associated biota in Dar es Salaam, Tanzania. Tanzania J. Sci. 29: 62 - 75 .

Muniz, P., Danulat E., Yannicelli B., Garcial-Alonso, J., Medina, G. and Becego, M.C. 2004. Assessment of contamination by heavy metal and petroleum hydrocarbons in sediments of Montevideo harbour (Uruguay). Environ. Int. 29: 1019 - 1028.

Murray, R.W., Miller, D. J.\& Kryc, K.A. 2000 Analysis of major and trace elements in rock, sediments and interstitial waters by Inductively Coupled Plasma-Atomic Emission Spectrometry (ICP-AES). Ocean Drilling Program, Texas A and M University, USA.

Ong, M. C., Kamaruzzaman, B. Y., Shazeli, N. A. M. \& Rosnan, Y. 2006. Distribution and Normalization of lead, copper and zinc in Terengganu mangrove surface sediment, Malaysia. J. Sustainability Sci. \& Manag. 1: 74-84.

Richmond, M.D. (ed) 2002. A field guide to the seashores of Eastern Africa and the Western Indian Ocean Islands. Sida/SAREC - UDSM. $461 \mathrm{pp}$. ISBN 91-586-8783-1.

Sarkar, S.K., Bhattacharya, A., Giri, S., Bhattacharya, B., Sarkar, D., Nayak, D.C. \& Chattopadhaya A..K. 2005. Spatiotemporal variation in benthic polychaetes (Annelida) and relationship with environmental variables in a tropical estuary. Wetlands Ecol. \& Manag. 13: 55 - 67

Semesi, A.K. 1991. Management plan for the mangrove ecosystem of the mainland Tanzania. Vol. 4. Mangrove Management plan of Dar es Salaam. Ministry of Tourism, natural Resources and Environment Forest and Beekeeping division. Dar es Salaam 292 p.

Thompson, M. \& Walsh, J.N. 2003. The handbook of Inductively Coupled Plasma Spectrometry. Viridian Publishing, Surrey. 316 pp

Wagner, G.M., Malya, U., Juma, S., Mgaya, Y.D. Wahule, O.\& Mahika, G. 1999. A preliminary investigation for an integrated Community based Approach to Conservation and Restoration of Marine Ecosystems along the Dar es salaam Coast. African Development Foundation, Dar es salaam $124 \mathrm{p}$

Zar, J. H. 1996. Biostatistical analysis. Second Edition. Prentice-Hall, Englewood Cliffs, New Jersey. 718pp. 